\title{
PENGARUH PERBANDINGAN SERBUK KAYU MANIS (Cinnamomum burmannii) DENGAN CENGKEH (Syzygium aromaticum L.) DAN KONSENTRASI GULA STEVIA (Stevia rebaudiana B.) TERHADAP KARAKTERISTIK TEH CELUP DAUN MENGKUDU (Morinda citrifolia L.)
}

\author{
Ina Siti Nurminabari \\ Tantan Widiantara \\ Wisa Irana \\ Program Studi Teknologi Pangan, Fakultas Teknik, Universitas Pasundan, Jl. Dr.Setiabudi No 93, Bandung, 40153, \\ Indonesia \\ E-mail : inasitinurminabari@unpas.ac.id
}

\begin{abstract}
Abstrak
Teh herbal adalah minuman yang terbuat dari bunga, daun, biji, akar atau buah kering tanpa menggunakan daun teh (Camelia sinensis). Penelitian ini bertujuan untuk mengetahui pengaruh penambahan serbuk kayu manis dengan cengkeh dan konsentrasi gula stevia terhadap karakteristik teh daun mengkudu. Metode penelitian ini menggunakan metode RAK (Rancangan Acak Kelompok) dengan pola faktorial 3 x 3. Metode penelitian ini dibagi dua, yaitu penelitian pendahuluan dan penelitian utama. Berdasarkan hasil penelitian pendahuluan didapatkan aktivitas antioksidan pada setiap bahan baku yaitu serbuk kayu manis, serbuk cengkeh, daun mengkudu kering dan pucuk daun mengkudu masing-masing sebesar 6,43 ppm, 7,51 ppm, 69,59 ppm, 75,71 ppm dan memiliki kadar air masing-masing sebesar $8 \%, 11 \%, 7 \%$, dan $12,72 \%$. Sedangkan pada penelitian utama didapat rata-rata kadar air pada teh daun mengkudu berkisar antara 7,33 \% - 9,33\%. Rata-rata kadar karbohidrat berkisar antara 1,28\% - 1,70\%. Serta aktivitas antioksidan pada seduhan teh daun mengkudu yaitu sebesar 747,132 ppm.
\end{abstract}

\begin{abstract}
Herbal tea is beverage or drink made of flower, leaf, seed, root or dried fruit without using the tea leaves (Camelia sinensis). The purpose of this research is to find the effect of increasing cinnamon powder with clove and stevia sugar concentrate through the characteristic of morinda citrifolia tea leaves. This research method is using a Randomized Block Design (RAK) with factorial 3 x 3. This research method is divided into 2 parts, those are preliminary research and principal research. Based on the preliminary research is obtained the antioxidant activity for all raw materials such as cinnamon powder, clove powder, dried morinda leaf, and tip of morinda leaf is 6,43 ppm, 7,51 ppm, 69,59 ppm, $75,71 \mathrm{ppm}$ and have the water content is $8 \%, 11 \%, 7 \%$, and $12,72 \%$. Meanwhile based on the main principal research, the water content in morinda tea leaves revolve in $7,33 \%-9,33 \%$. The carbohydrate content revolve in $1,28 \%-1,70 \%$. And also the antioxidant activity of boiling morinda tea leaves is 747,132 ppm.
\end{abstract}

Keyword : Morinda leaf, antioxidant activity, tea, herbal tea

\section{Pendahuluan}

Teh merupakan functional food mengingat khasiat dan potensi yang terkandung dalam teh dapat meningkatkan kesehatan tubuh dan merupakan sumber zat gizi. Saat ini telah banyak berkembang minuman fungsional yang bersumber tidak hanya dari teh, tetapi bahan-bahan alami lainnya digunakan sebagai minuman fungsional yang dikenal dengan bahan-bahan herbal. Bahan-bahan herbal adalah sebutan untuk ramuan, bunga, daun, biji, akar atau buah kering untuk membuat minuman yang juga disebut teh herbal.

Walaupun disebut "teh", ramuan atau minuman ini tidak mengandung daun dari tanaman teh (Camellia sinesis) (Mun'im dkk, 2008).

Teh herbal merupakan salah satu produk minuman tanaman herbal yang memiliki khasiat dalam membantu pengobatan suatu penyakit atau sebagai penyegar. Teh herbal tidak berasal dari tanaman daun teh yaitu Camellia sinesis. Teh herbal dapat dikonsumsi sebagai minuman sehat yang praktis tanpa mengganggu rutinitas sehari-hari dan tetap menjaga kesehatan tubuh. (Hambali, dkk, 2006), (Winarsi, 2011).

Daun mengkudu di daerah Jawa Barat khususnya dataran sunda, biasanya dikonsumsi langsung tanpa diolah terlebih dahulu (mentah) sebagai lalapan. Sebagimana sayuran pada umumnya, daun mengkudu sangat kaya akan protein, provitamin A, serta beberapa mineral seperti fosfor, kalsium, zat besi, dan selenium. Selain itu daun mengkudu juga mengandung senyawa aktif seperti flavonoid, iridoid, asam askorbat, karoten dan riboflavin. Daun mengkudu juga mengandung senyawa antrakuinon, alkaloid, saponin, terpenoid yang berperan sebagai antibakteri. Salah satu usaha lain untuk meningkatkan nilai dari daun mengkudu ialah dengan 
memanfaatkannya menjadi teh herbal dengan menggunakan daun mengkudu (Yuliawaty dan Susanto, 2015).

Kandungan kimia dari kayu manis antara lain minyak atsiri, safrole, sinamaldehida, tanin, dammar, kalsium oksalat, flavonoid, triterpenoid, dan saponin. Secara umum, komposisi kimia minyak kayu manis terdiri sinamaldehida, sinamilasetat, salisaldehida, asam sinamat, asam salisilat, asam benzoat, eugenol, dan metilsalisaldehida dengan komponen sinamaldehida sebagai komponen utama minyak kayu manis (Utami dan Puspaningtyas, 2013).

Cengkeh atau tanaman dengan nama latin Syzygium aromaticum $L$. merupakan tanaman herba yang berasal dari Maluku. Tanaman ini memiliki kandungan senyawa aktif dalam tanaman cengkeh yang memiliki manfaat kesehatan adalah minyak atsiri, eugenol, asam oleanolat, fenilin, karyofilin, resin, dan gom. Kandungan utama yang memberikan manfaat kesehatan adalah minyak cengkeh, dengan komposisi utama antara lain eugenol, caryophyllene, eugenol acetate, dan alphahumelene (Utami dan Puspaningtyas, 2013).

Gula stevia berasal dari tanaman stevia yaitu bagian daunnya. Rasa manis pada daun stevia berasal dari kandungan glikosida yang terdiri dari 2 komponen utama yaitu steviosida (3-10\% dari berat kering daun) dan rebaudiosida (1-3\% dari berat kering daun). Daun kering stevia mempunyai tingkat kemanisan 2,5 kali dari sukrosa (gula tebu). Sejak tahun 2008, Food and Drug Administration (FDA) mengijinkan stevia digunakan sebagai bahan tambahan pangan, FDA menggolongkan stevia dalam kategori GRAS (Generally Recognize As Safe) dengan batas konsumsi ADI (Acceptable Daily Intake) sebanyak 4 $\mathrm{mg} / \mathrm{kgBB} /$ hari (Hastuti dan Rustanti, 2014).

Prinsip pembuatan teh celup daun mengkudu ini menggunakan prinsip pengeringan. Tujuan pengeringan ini agar produk teh celup daun mengkudu ini mengandung kadar air yang rendah, sehingga dapat disimpan dalam jangka waktu yang lama.

\section{Metode Penelitian}

Penelitian yang akan dilakukan terdiri dari dua tahap, yaitu penelitian pendahuluan dan penelitian utama. Penelitian pendahuluan bertujuan untuk mengetahui kadar air dan aktivitas antioksidan pada setiap bahan baku, sedangkan pada penelitian utama bertujuan untuk mengetahui pengaruh penambahan perbandingan serbuk kayu manis dengan cengkeh dan konsentrasi gula stevia serta inteeraksinya. Rancangan perlakuan pada penelitian ini terdiri dari 2 faktor yaitu perbandingan serbuk kayu manis dengan cengkeh $(\mathrm{P})$ dan konsentrasi gula stevia $(\mathrm{G})$, yang masing-masing terdiri dari 3 taraf.
Rancnagan percobaan yang digunakan dalam penelitian utama adalah pola faktorial $(2 \times 3)$ dalam Rancnagan Acak Kelompok (RAK) dengan 3 kali ulangan, sehingga diperoleh sebanyak 27 satuan percobaan.

Rancnagan respon yang akan dilakukan pada penelitian ini, meliputi: respon kimia dan respon organoleptik. Respon kimia yang dilakukan dalam penelitian utama meliputi analisis kadar air menggunakan metode gravimetri dan analisis aktivitas antioksidan metode DPPH. Respon organoleptik yang dilakukan pada penelitian utama ini meliputi atribut warna, aroma dan rasa. Serta adanya penentuan produk terpilih yang kemudian akan dianalisis aktivitas antioksidannya.

\section{Hasil dan Pembahasan \\ Hasil Penelitian Pendahuluan}

Tujuan dari penelitian pendahuluan ini yaitu untuk mengetahui aktivitas antioksidan dan untuk mengetahui kadar air dari setiap bahan baku. Penelitian pendahuluan berupa analisis aktivitas antioksidan dan analisis kadar air dilakukan pada pucuk daun mengkudu, daun mengkudu kering, serbuk kayu manis, dan serbuk cengkeh.

Tabel 1. Hasil Analisis Penelitian Pendahuluan

\begin{tabular}{|c|c|c|c|}
\hline \multirow{2}{*}{ Bahan Baku } & \multicolumn{3}{|c|}{ Hasil Analisis } \\
\cline { 2 - 4 } & $\begin{array}{c}\text { Kadar } \\
\text { Air (\%) }\end{array}$ & $\begin{array}{c}\text { Nilai IC50 } \\
\text { (ppm) }\end{array}$ & $\begin{array}{c}\text { SNI } \\
\text { Kadar Air }\end{array}$ \\
\hline Serbuk Kayu Manis & 8 & 6,43 & Maks.12\% \\
\hline Serbuk Cengkeh & 11 & 7,51 & Maks.12\% \\
\hline $\begin{array}{c}\text { Daun Mengkudu } \\
\text { Kering }\end{array}$ & 7 & 69,59 & Maks.10\% \\
\hline $\begin{array}{c}\text { Pucuk Daun } \\
\text { Mengkudu }\end{array}$ & 12,72 & 75,71 & - \\
\hline
\end{tabular}

Keterangan: (-) tidak ada SNI acuan.

Kadar air serbuk kayu manis dengan serbuk cengkeh masing-masing sebesar $8 \%$ dan $11 \%$, dimana kadar air tersebut telah memenuhi standar mutu. Standar mutu kadar air serbuk kayu manis ini mengacu pada SNI nomor 01-3714-1995, dimana kayu manis bubuk memiliki kadar air maksimal 12,00\%. Sedangkan standar mutu serbuk cengkeh mengacu pada SNI nomor 01-3709-1995, dimana kadar air rempah-rempah bubuk maksimal sebesar $12,00 \%$.

Daun mengkudu kering memiliki kandungan air sebesar $7 \%$, yang artinya daun mengkudu kering ini telah memenuhi standar mutu. Standar mutu serbuk daun mengkudu ini mengacu pada SNI teh hijau celup nomor 01-4324-1996, dimana standar kadar air pada teh hijau celup ini maksimal memiliki kadar air sebesar $10 \%$. 
Tabel 2. Tingkat Kekuatan Antioksidan dengan Metode DPPH

\begin{tabular}{|c|c|}
\hline Intensitas & Nilai IC50 (ppm) \\
\hline Sangat Kuat & $<50$ \\
\hline Kuat & $50-100$ \\
\hline Sedang & $101-150$ \\
\hline Lemah & $>150$ \\
\hline
\end{tabular}

Sumber: Ariyanto (2006), dalam Wirani (2017)

Aktivitas antioksidan pada serbuk kayu manis dan serbuk cengkeh sebesar 6,43 ppm dan 7,51 yang termasuk ke dalam intensitas yang sangat kuat. Sedangkan pada daun mengkudu kering dan pucuk daun mengkudu masing-masing sebesar 69,59 ppm dan 75,71 ppm yang termasuk ke dalam intensitas yang kuat.

Hasil uji organoleptik terhadap tahu koro pedang dengan faktor jenis koagulan dan suhu pemasakan dengan atribut warna, aroma, rasa dan tekstur untuk menentukan perlakuan terpilih dapat dilihat pada Tabel 1 .

\section{Hasil Penelitian Utama}

1. Analisis Kadar Air

Tabel 3. Tabel Uji Lanjut Duncan Perbanding Serbuk

Kayu Manis dengan Serbuk Cengkeh Terhadap Kadar

\begin{tabular}{|c|c|c|}
\multicolumn{4}{|c|}{ Air } \\
$\begin{array}{c}\text { Perbandingan Serbuk } \\
\text { Kayu Manis dengan } \\
\text { Serbuk Cengkeh }\end{array}$ & $\begin{array}{c}\text { Nilai Rata- } \\
\text { rata }\end{array}$ & $\begin{array}{c}\text { Taraf } \\
\text { Nyata 5\% }\end{array}$ \\
\hline p1 (1:2 ) & $8,00 \%$ & a \\
\hline p2 (1:1) & $8,78 \%$ & b \\
\hline p3 ( 2:1 ) & $7,66 \%$ & a \\
\hline
\end{tabular}

Keterangan : Nilai rata-rata yang ditandai dengan huruf yang sama menunjukkan perlakuan tidak berbeda nyata pada taraf $5 \%$.

Berdasarkan tabel uji lanjut Duncan dapat disimpulkan bahwa dengan semakin meningkatnya jumlah kayu manis yang ditambahkan terjadi peningkatan kadar air yang nyata yang diikuti penurunan yang nyata $\mathrm{p} 1$ terhadap $\mathrm{p} 2$ dan $\mathrm{p} 2$ terhadap p3.

Penurunan yang nyata pada kadar air dengan penambahan serbuk kayu manis diduga terjadi karena sifat kayu manis yang higroskopis, yaitu kemampuan bahan dalam menyerap air. Semakin banyak kayu manis yang ditambahkan, maka kemampuan kayu manis dalam mengikat air pun akan meningkat, sehingga air yang diserap semakin banyak dan menyebabkan penurunan kadar air yang nyata pada perlakuan $\mathrm{p} 3$.

Menurut Bowyer (2013) kayu manis memiliki sifat higroskopis yaitu kemampuan untuk menyerap dan melepaskan air, baik dalam bentuk cairan maupun uap air. Diduga ketika ekstraksi, kayu manis menyerap air yang sengaja ditambahkan untuk mengoptimalkan proses ekstraksi. Perubahan kadar air kayu manis akan berpengaruh terhadap dimensi dan sifat-sifat kayu, seperti tekstur, dan warna.
2. Analisis Kadar Karbohidrat

Tabel 4. Uji Lanjut Duncan Pengaruh Konsentrasi Gula Stevia terhadap Kadar Karbohidrat Teh Daun Mengkudu

\begin{tabular}{|c|c|c|}
\hline $\begin{array}{c}\text { Konsentrasi Gula } \\
\text { Stevia }\end{array}$ & $\begin{array}{c}\text { Rata-rata } \\
\text { Perlakuan (\%) }\end{array}$ & Taraf 5\% \\
\hline $1 \%$ & 1,29 & $\mathrm{~A}$ \\
\hline $2 \%$ & 1,47 & $\mathrm{~B}$ \\
\hline $3 \%$ & 1,66 & $\mathrm{C}$ \\
\hline
\end{tabular}

Keterangan : Nilai rata-rata yang ditandai dengan huruf yang sama menunjukkan perlakuan tidak berbeda nyata pada taraf 5\% menurut uji lanjut Duncan.

Dari tabel di atas dapat disimpulkan bahwa dengan meningkatnya konsentrasi gula stevia terjadi peningkatan yang nyata terhadap kadar karbohidrat yang nyata pada $\mathrm{p} 1$ terhadap $\mathrm{p} 2$ dan $\mathrm{p} 2$ terhadap $\mathrm{p} 3$.

Hal ini terjadi karena semakin banyaknya gula stevia yang ditambahkan maka semakin bertambah pula kadar gula pereduksi. Diperkuat dengan pernyataan Mayanningtyas (2016) yang mengatakan bahwa semakin banyak penambahan tepung daun stevia dan hidrolisis sukrosa yang terjadi dapat meningkatkan kadar gula reduksi.

3. Uji Organoleptik

a. Warna

Tabel 5. Uji Lanjut Duncan Pengaruh Perbandingan Antara Serbuk Kayu Manis dengan Serbuk Cengkeh

\begin{tabular}{|c|c|c|}
\hline $\begin{array}{c}\text { Serbuk Kayu Manis : } \\
\text { Serbuk Cengkeh }\end{array}$ & $\begin{array}{c}\text { Rata-Rata } \\
\text { Perlakuan }(\%)\end{array}$ & Taraf 5\% \\
\hline p1 $(1: 2)$ & 2,68 & $\mathrm{~A}$ \\
\hline $\mathrm{p} 2(1: 1)$ & 2,69 & $\mathrm{~A}$ \\
\hline p3 $(2: 1)$ & 3,13 & $\mathrm{~B}$ \\
\hline
\end{tabular}

Keterangan : Nilai rata-rata yang ditandai dengan huruf yang sama menunjukkan perlakuan tidak berbeda nyata pada taraf 5\% menurut uji lanjut Duncan.

Dilihat pada Tabel 18 dapat disimpulkan bahwa dengan semakin meningkatnya jumlah kayu manis tidak terjadi peningkatan yang nyata pada atribut warna pada $\mathrm{p} 1$ terhadap $\mathrm{p} 2$ tetapi meningkat nyata pada $\mathrm{p} 2$ terhadap $\mathrm{p} 3$.

Hal ini diperkuat oleh penelitian Zainuddinunur, dkk (2016) berdasarkan hasil uji organoleptik warna pada "Proses Pembuatan Teh Herbal Daun Sukun dengan Optimasi Proses Pengeringan dan Penambahan Bubuk Kayu Manis dan Cengkeh", warna yang paling banyak disukai oleh panelis adalah teh daun sukun dengan penambahan $8,7 \%$ kayu manis dan 4,3\% cengkeh. Warna yang ditimbulkan adalah kuning kecoklatan, hal ini dipengaruhi oleh penambahan kayu manis yang lebih banyak daripada sampel lainnya, hal ini membuktikan bahwa warna yang lebih disukai oleh panelis adalah warna kuning kecoklatan pada produk teh, hal ini sesuai dengan penelitian Arpah (1993), bahwa senyawa teaflavin memberikan warna merah kekuningan, terang dan berpengaruh terhadap kejernihan seduhan. 
Selain perbandingan bahan, faktor-faktor yang mempengaruhi proses penyeduhan yaitu faktor suhu dan waktu penyeduhan. Semakin tinggi suhu air maka kemampuan air untuk mengekstrak senyawa kimia yang terkandung di dalam teh akan semakin tinggi. Demikian pula dengan waktu atau lama penyeduhan. Waktu akan sangat berpengaruh terhadap kadar kandungan bahan kimia yang terlarut, intensitas warna serta aroma teh yang akan dikomsumsi.

Teknik penyeduhan cukup bermanfaat menghasilkan senyawa antioksidan secara maksimal. Proses penyeduhan tersebut berfungsi mempertahankan kualitas senyawa yang kita inginkan. Sehingga tidak terjadi degradasi terhadap kandungan senyawa kimia teh. Secara umum semakin tinggi suhu penyeduhan maka semakin besar pula kemampuan air untuk mengekstrak dan mengikat senyawa yang ada dalam teh (Ramlah, 2017).

b. Aroma

Tabel 6. Hasil Analisis Variansi (ANAVA) terhadap Aroma Seduhan Teh Daun Mengkudu

\begin{tabular}{|c|c|c|c|c|c|}
\hline SV & DB & JK & KT & F. Hit & F. Tab \\
\hline Kel & 2 & 0,439 & 0,219 & & \\
\hline Per & 8 & 1,301 & 0,163 & & \\
\hline P & 2 & 0,439 & 0,219 & $2,00^{\text {tn }}$ & 3,63 \\
\hline G & 2 & 0,492 & 0,246 & $2,24^{\text {tn }}$ & 3,63 \\
\hline PG & 4 & 1,301 & 0,325 & $2,96^{\text {tn }}$ & 3,01 \\
\hline Galat & 16 & 1,756 & 0,110 & & \\
\hline Total & 26 & 4,426 & 0,170 & & \\
\hline
\end{tabular}

Dari data di atas dapat disimpulkan bahwa penambahan perbandingan serbuk kayu manis dengan serbuk cengkeh, penambahan gula stevia dengan konsentrasi yang berbeda serta interaksinya tidak berpengaruh nyata terhadap aroma teh celup daun mengkudu, sehingga tidak perlu dilakukan uji lanjut Duncan.

Hal ini bisa terjadi karena penambahan serbuk kayu manis, cengkeh serta gula stevia yang ditambahkan hanya sedikit, sehingga aroma yang keluar dari teh celup daun mengkudu hanya aroma dari daun mengkudunya saja. Masing-masing perlakuan hanya memiliki perbandingan sangat kecil.

Aroma khas daun mengkudu kemungkinan berasal dari senyawa aromatik seperti seyawa ester, alkohol, asam, aldehid, keton, diasetil, asetilkarbinol, geraniol dan senyawa fenol yang bersifat folatil (Apandi, 2014). Kemungkinan lain aroma daun mengkudu berasal dari reaksi antara gula reduksi dan asam amino atau terjadinya reaksi Maillard yang menghasilkan aroma khas (Saragih, 2014). c. Rasa

Tabel 7. Hasil Analisis Variansi (ANAVA) terhadap Rasa Seduhan Teh Daun Mengkudu

\begin{tabular}{|c|c|c|c|c|c|}
\hline SV & DB & JK & KT & F. Hit & F. Tab \\
\hline Kel & 2 & 0,172 & 0,086 & & \\
\hline Per & 8 & 4,125 & 0,516 & & \\
\hline P & 2 & 0,172 & 0,086 & $0,20^{\text {tn }}$ & 3,63 \\
\hline G & 2 & 1,312 & 0,656 & $1,51^{\text {tn }}$ & 3,63 \\
\hline PG & 4 & 4,125 & 1,031 & $2,37^{\text {tn }}$ & 3,01 \\
\hline Galat & 16 & 6,950 & 0,434 & & \\
\hline Total & 26 & 12,730 & 0,490 & & \\
\hline
\end{tabular}

Dari data di atas dapat disimpulkan bahwa penambahan perbandingan serbuk kayu manis dengan serbuk cengkeh, penambahan gula stevia dengan konsentrasi yang berbeda serta interaksinya tidak berpengaruh nyata terhadap rasa teh celup daun mengkudu, sehingga tidak perlu dilakukan uji lanjut Duncan

Hal ini terjadi karena penambahan setiap bahan hanya sedikit, sehingga tidak mempengaruhi rasa yang ditimbulkan oleh teh celup daun mengkudu. Rasa yang dihasilkan adalah rasa dari daun mengkudunya saja, menurut salah satu panelis, dan memiliki aftertaste pahit.

Rasa pahit dan sepat yang dihasilkan disebabkan oleh suhu pengeringan yang tidak terlalu tinggi. Menurut Saragih (2014) rasa pahit dan getir teh daun mengkudu kurang terasa karena kandungan minyak atsiri berkurang setelah dikeringkan pada suhu $70^{\circ} \mathrm{C}$ dengan waktu pengeringan 3,5 jam. Menurut Kataren (1985), minyak atsiri dapat menguap pada suhu kamar dan penguapan semakin besar dengan kenaikan suhu.

4. Produk Terpilih

Produk terpilih diperoleh dari pengujian organoleptik dengan uji hedonik yang kemudian diubah ke dalam uji skoring. Sampel yang memiliki skor terbesar adalah sampel p3g3, kemudian dianalisis aktivitas antioksidannya.

Tabel 8. Hasil Analisis Produk Terpilih

\begin{tabular}{|c|c|c|}
\hline Analisis & Nilai IC50 & Kategori \\
\hline Aktivitas & 747,132 & $\begin{array}{c}\text { Sangat } \\
\text { Lemah }\end{array}$ \\
Antioksidan & & P \\
\hline
\end{tabular}

Berdasarkan data hasil analisis produk terpilih, didapatkan bahwa aktivitas antioksidan memiliki nilai IC50 sebesar 747,132, dimana nilai IC50 ini > 150 sehingga termasuk ke dalam golongan antioksidan yang sangat lemah. Terjadinya penurunan aktivitas antioksidan pada seduhan teh celup daun mengkudu bila dibandingkan dengan daun mengkudu kering karena pada saat dilakukan analisis aktivitas antioksidan menggunakan pelarut metanol.

Hal ini dikarenakan kemampuan dan sifat pelarut dalam melarutkan senyawa flavonoid berbeda- beda, tergantung dari tingkat kepolaran pelarut dan senyawa yang diekstrak. Menurut prinsip polarisasi, suatu 
senyawa akan larut pada pelarut yang mempunyai kepolaran yang sama (Harborne, 1987).

Senyawa flavonoid merupakan senyawa polar karena mempunyai sejumlah gula yang terikat, oleh karena itu flavonoid lebih cenderung larut pada pelarut polar. Menurut Harborne (1987) senyawa flavonoid terbagi menjadi beberapa jenis, tiap jenis flavonoid mempunyai kepolaran yang berbeda beda tergantung dari jumlah dan posisi gugus hidroksil tiap jenis flavonoid sehingga hal tersebut akan mempengaruhi kelarutan flavonoid pada pelarut.

Senyawa antioksidan yang berpengaruh pada daun mengkudu kering adalah flavonoid. Tingginya aktivitas antioksidan pada daun mengkudu kering dengan pelarut metanol menjelaskan bahwa karakteristik senyawa flavonoid pada ekstrak daun mengkudu kering mempunyai kepolaran yang sama dengan metanol, sehingga ekstrak daun mengkudu kering dengan pelarut metanol menghasilkan kandungan senyawa flavonoid tertinggi.

Berdasarkan hasil penelitian, dapat diambil kesimpulan sebagai berikut :

1. Penelitian pendahuluan menghasilkan kadar air pada serbuk kayu manis, serbuk cengkeh, daun mengkudu kering dan pucuk daun mengkudu masing-masing sebesar $8 \%, 11 \%, 7 \%$, dan $12,72 \%$. Serta menghasilkan aktivitas antioksidan pada serbuk kayu manis, serbuk cengkeh, daun mengkudu kering dan pucuk daun mengkudu masing-masing sebesar 6,43 ppm, 7,51 ppm, 69,59 ppm, 75,71 ppm.

2. Perbandingan serbuk kayu manis dengan serbuk cengkeh berpengaruh terhadap respon kimia meliputi kadar air dan berpengaruh terhadap respon organolepik meliputi atribut warna

3. Konsentrasi gula stevia berpengaruh terhadap respon kimia meliputi kadar karbohidrat.

4. Interaksi antara perbandingan serbuk kayu manis dengan cengkeh dan konsentrasi gula stevia tidak berpengaruh terhadap respon kimia dan organoleptik.

\section{Daftar Pustaka}

1. Hambali, E.M.Z. Nasution dan E. Herliana. 2005. Membuat Aneka Herbal Tea. Jakarta. Penebar Swadaya.

2. Hastuti, A. M., dan R. Ninik. 2014. Pengaruh Penambahan Kayu Manis terhadap Aktivitas Antioksidan dan Kadar Gula Total Minuman Fungsional Secang dan Daun Stevia sebagai Alternatif Minuman Bagi Penderita Diabetes Melitus Tipe 2. Program Studi Ilmu Gizi. Universitas Diponegoro. Semarang.

3. Mun'im, Abdul, dkk. 2008. Pembuatan Teh Herbal Campuran Kelopak Bunga Rosella dan Herba Seledri. Depok : UI. Jurnal.

4. Utami, P., dan Puspaningtyas, D. E. 2013. The Miracle of Herbs. Jakarta. PT AgroMedia Pustaka.
5. Wirani, R. 2017. Kajian Perbandingan Daun Dengan Ampas Buah Black Mulberry (Morus Nigra) Serta Lama Pengeringan Terhadap Karakteristik Teh Celup. Program Studi Teknologi Pangan. Bandung.

6. Yulia, A., Rahmi SL. Studi Pembuatan Minuman Kayu Manis Berkarbonasi Dengan Penambahan Gula Pasir Dan Natrium Bikarbonat. Jurnal penelitian Universitas Jambi seri sains; 2011 Januari-April: 13(1): 53-8

7. Yuliawati, S. T., dan W. Hadi Susanto. 2015. Pengaruh Lama Pengeringan dan Konsentrasi Maltodekstrin terhadap Karakteristik Fisik Kimia dan Organoleptik Minuman Instan Daun Mengkudu (Morinda citrifolia L). Jurusan Teknologi Hasil Pertanian. Universitas Brawijaya Malang. Malang. 